\title{
Самогубство як втрата моральних та екзистенційних цінностей
}

Анотація. Дана робота присвячена проблематиці самогубства. За основу статті взята творча спадщина I. О. Сікорського, щзо стосується цієї теми. У роботі наведений перелік професій, де найчастіме здійснюються самогубства, та зроблений аналіз причин їх виникнення. Виділені вікові категорії, в яких відбувається найбільша кількість самогубств, та фактори, що штовхають людей до такого трагічного кроку. Акценнтовано увагу на тому, щзо однією з найрозповсюджених причин виникнення суїииду являється криза моральних та екзистенційних иінностей. Для подолання цієї проблеми наголошується на проведені різноманітної роботи спрямованої на створення та підкріплення цінностей та орієнтирів, особливо моральних.

Ключові слова: мораль, моральність, суїиид, моральні та екзистенційні цінності, формування ідеалізму, виховання.

Постановка проблеми. Існування суїциду, чи добровільного припинення свого життя можна простежити впродовж усієї історії людства. В залежності від суспільного ладу, релігії, традицій та звичаїв домінували крайньо протилежні точки зору на даний вчинок. 3 року в рік кількість скоєних самогубств зростає. Виникає цілком логічне запитання: «Чому з розвитком цивілізації, збільшенні кількості населення, відбувається ріст суїцидів?».

Мета дослідження. Проаналізувати чинники, які провокують виникнення суїциду та визначити шляхи їх подолання.

Аналіз останніх досліджень і публікацій. Досить часто, читаючи газету чи сприймаючи інші засоби мас-медіа, наштовхуємося на інформацію про суїцид. Що слугує причиною такої широкої відомості? «За інформацією Всесвітньої організації охорони здоров'я (ВОO3) у другій половині XX ст. самогубства вийшли на третє місце (після серцево-судинних і онкозахворювань) серед причин смерті» [1, с. 29]. На нашій планеті кожний рік зводить рахунки 3 життям від 1 млн. до 4 млн. людей. Щорічно близько 19 млн. чоловік здійснює невдалі спроби самогубства. Україна належить до групи країн з надвисоким рівнем суїциду (понад 16 осіб на 100000 населення). Згідно статистики ВООЗ за останніх декілька років в Україні щорічно гине 22-26 ч. на 100000 населення — це близь- ко 12000 в рік. Рівень суїцидів в нашій країні збільшувався до 1995 р., а починаючи з 2000 р. трохи знизився. Згідно даних Державної служби статистики України кількість людей, що завершили життя самогубством в 2011 p. - 9000, в 2012 р. — 9049 ч., на перше півріччя 2013-4749 ч. Проте 3'явився інший негативний аспект кількість таких випадків серед осіб 15-30 p. значно зросла.

Та перш ніж розпочати розгляд цього питання, давайте визначимо, що будемо вважати за суїцид. Серед спеціалістів різних професій (психіатрів, соціологів, філософів, психологів та інші) переважає визначення, що суїцид - самогубство (лат., sui себе, caedo - вбивати) - це усвідомлена навмисна дія, спрямована на добровільне позбавлення себе життя, що призвела до смерті. Вивченням проблеми самогубства займається багато наук. Право першості серед них належить психології і філософії. Чому? Один 3 найвідоміших спеціалістів по суїцидології в США та й в усьому світі Едвін Шнейдман (1918-2009) був переконаний: «...самогубство є драмою, яка відбувається першою чергою в душі людини», а не в хімічній зміні ії організму, чи впливі певних природних явищ. Вчений вважав, що суїцид потрібно розглядати як аутоагресію, котра викликана дуже сильним душевним болем, в основі якого лежать невдачі в задоволені психологічних 
потреб. Дане трактування не відноситься до розповсюджених в наш час терористичних та відживаючих ритуальних самогубств.

Виникає цілком логічне запитання: «Чому з розвитком цивілізації, збільшенні кількості населення, відбувається ріст самогубств?»

Суїцид має переважно індивідуальне коріння, на чому в свій час наголошував I. О. Сікорський: «...в більшості випадків прагнення до самознищення викликано було швидше суб'єктивним станом, ніж зовнішніми подіями. Зовнішні ж події, в цих випадках, слугували лише приводом до самознищення, а зовсім не причиною: істинна причина корінилась в хворобливому настрою і в давньому, готовому песимізмі, яким жили окремі особи...» [2, с. 504]. Люди не вчиняють самогубство спонтанно. «В більшості випадків людину детермінують абстрактні, продумані мотиви, а не враження поточного моменту» [8, с. 44]. Між тим, як людина стала на шлях самогубства і її смертю, проходить певний час. Протягом якого все нові і нові події підштовхують їі до цього вчинку. А та подія (i), яку зазвичай трактуємо, тією що стала приводом до самогубства, є лише останньою краплиною в переповненій чаші. В переважній кількості випадків сама людина не пам'ятає, коли вона стала на цей шлях. І.О. Сікорський писав 3 цього приводу: «Не тільки почуття і ефекти, як відкрив Фрейд, а й всі взагалі психічні акти можуть загубитись в душі, щоб колинебудь в майбутньому випірнути з глибини несвідомого психічного океану і принести з собою для людини добру чи не добру послугу» [3, с. 6]. «Будь-який психічний акт може загубитись: почуття, думка, вольове напруження, руховий заряд, психічна директива. Так, нерідко спалахує в душі почуття вини в своїй найгострішій, пекучій, безпощадній формі...» [3, с. 6]. Людина хоче позбутися цього болю, i, нерідко, в такому стані в неї виникає думка про самогубство, яка під впливом певних обставин може реалізуватись. (Ряд вчених (В. Поллак, В. Жильцова) схиляється до того, що суїцид є одним із механізмів самозахисту, i людина намагається з допомогою нього вийти із складної ситуації). А що для людини почуття вини? «В основі почуття вини лежить занепад сил, зниження фізіологічного та психологічного потенціалу, занепад духу і визнання себе причиною змін, що наступили» [3, с. 15]. В людини виникає моральне страждання, яке важче подолати чим фізичне. Моральне страждання чинить безпосередній вплив і на душевний стан, i на фізичний. «Моральні страждання призводять до головного болю і, інколи, до зупинки серця» [4, с. 123]. Звідси випливає: почуття вини $є$ причиною зниження як фізичної, так і психологічної активності, без залежності звідки беруть початок його коріння: чи в внутрішньому, чи в зовнішньому світі. Воно завжди $є$ деструктивним чинником для здоров'я людини. Хоча 3 iншої боку - ефективним чинником духовного зростання.

I.O. Сікорський виділяв такі головні причини занепаду духу:

- «по-перше, уповільнення і зупинка думки (в сумнівах);

- по-друге, уповільнення і зупинка волі (в нерішучості і ваганні);

- по-третє, залежне від фізіологічних причин: втомлюваність роботою, отруєння організму токсинами і від нервового виснаження під впливом пристрастей та ексцесів» [3, с. 15].

Вплив перерахованих причин можна спостерігати у житті значної частини людства, проте необов'язково вони призводять до самогубства. В когось виникнути розчарування, депресія, а в декого бажання звести рахунки $з$ життям. Появу думки про самогубство потрібно вважати тим переломним моментом, після якого людина крок за кроком наближається до реалізації свого задуму. «....сама думка про самогубство, як допустимому і можливому акті, особливо ж, втілена в конкретні форми місця, часу, знарядь, обставин і ін., може стати роковою, подібно спробі стати для експерименту біля прірви» [3, с. 7]. Таким чином людина створює модель поведінки, яка при «певних» обставинах, як одна 3 форм са- 
мого зручного реагування (всі основні дії від самого початку до кінця уже продумані), запускається в дію. Людина діє так би мовити «автоматично». «Ще небезпечніші цілі директиви на рахунок самогубства: наприклад, план застрелитися чи отруїтися при певних умовах, при настанні того чи іншого моменту, при тій або іншій невдачі, при такій чи іншій безвихідності. Всі директиви подібного роду глибоко невірні по суті, так як, будучи психологічно заготовлені заздалегідь, вони позбавляють свого нещасного автора можливості оцінити останній момент, який повинен грати роль сигнального акту і вирішальної ланки в ланцюгу подій» [3, с. 7-8].

Ще ближче людина наближається до суїциду, коли вона проговорює свій план самогубства. Таким чином вона робить наступний крок на шляху до самознищення. «...словесне втілення вже $є$ початком волі i pуху...» $[3$, с. 7$]$. Не потрібно залишати без уваги те, що проговорення дійства викликає інші психологічні процеси, такі, наприклад, як звукова пам'ять, які при «певних» обставинах сприяють запуску моделі поведінки на самознищення. «Це або іншого роду сміття, яке вноситься в душу (в пам'ять) є саме сміття, веде до забруднення красоти і чистоти духу і вказує на легковажне відношення до найвеличніших психічних цінностей, які вимагають поваги до себе і виключають будь-яку тінь легкого або недбалого відношення» [3, с. 7].

Наступним кроком, який наближає до самогубства, $є$ підготовка речей для його реалізації. «Ще небезпечніші вольові акти, т. б. рішення і програми, особливо початок виконання програми: наприклад, заготівля та тримання в себе отрути, вогнепальної зброї, навіть без думки про найближчу необхідність в тім, а лише тільки, як програмний або перспективний акт» [3, с. 7]. Потрапляючи в поле зору, час від часу ці речі будуть нагадувати людині, з якою ціллю вони тут знаходяться, що також $є$ певним підштовхуючим до самогубства чинником.

Які ж категорії людей найбільш схильні до самогубства? За статистикою, почина- ючи 3 даних I. О. Сікорського, переважна кількість суїцидів відбувається серед військових та людей інтелектуальної професії (вчителів, юристів, особливо лікарів). Якщо брати за віковою категорією, то останнім часом значно зріс рівень самогубств серед підлітків та молоді.

Виходячи $з$ різних даних, самогубства в арміях країн колишнього СРСР «...становлять 18-50 \% від загальної кількості смертей в мирний час. Якщо в 1993 році в українській армії показник самогубств був рівний 200 на 100000 військовослужбовців, то в $1994-340$ » [5, с. 23]. Це пов'язано 3 виснажливим характером їх діяльності, поганою соціальною захищеністю, сімейними обставинами, хронічною втомою, важкими психологічними травмами, отриманими під час бойових дій. I. О. Сікорський виділяв ще такі чинники: значно більше навантаження на вищі психічні функції, особливо увагу (слухову, зорову), моральне навантаження, що призводить до розумової втоми. «Але значно більше значення для нашого солдата мають труднощі в моральній орієнтації, внаслідок переходу від сільського життя - до міського, від сімейного - до казарменого; виникаючі звідси психологічні ускладнення грають суттєву роль як одна з причин, схильності до самогубства» [6, с. 13].

Існують думки, що коли армія перейде на контрактну службу, і в ній будуть працювати одні професіонали, кількість самогубств наблизиться до нуля. Та як свідчать статистичні дані країн, у котрих контрактна армія, взяти хоча б для прикладу США, число суїцидів в колі військових високе - «Серед американських чоловіків в віці від 17 до 60 років щорічно приходиться в середньому 25 самовбивств на 100 тисяч цивільних і 17,5 - на 100 тисяч військово службовців» [7]. Це число нижче, ніж в українській армії, проте все ж значне.

Наступне місце серед кількості вчинених самогубств займають люди «інтелектуальної професії». До них І. О. Сікорський відніс тих, які займаються «наукою i літературою, чиновників, юристів, лікарів, артистів, духовні звання (духовенство)». 
«Дані, щодо впливу інших професій, показують, що друге місце після військової професії займає так названа ліберальна професія (інтелектуальна праця), яка потребує напруженої мозкової діяльності» [6, с. 14].

Серед людей «інтелектуальної профеciї» розглянемо таку групу, як медики. Вибір зупинимо саме на них, тому що по кількості самогубств вони випереджають всіх інших. «Кількість самогубств серед російських лікарів перевершує кількість самогубств всіх інших станів і професій не тільки у нас, але й за кордоном» [6, с. 9]. Ця тенденція з деякими змінами існує більше 100 р. Для підтвердження приведемо дані з останніх досліджень зроблених в США: «...в середовищі медиків спостерігається значно більший рівень самогубств в порівнянні 3 таким серед решти населення», «...самовбивства серед лікарів-чоловіків відбуваються на $40 \%$ частіше, а серед жінок - на $130 \%$ частіше, чим серед осіб, які не мають медичної освіти» [9].

Які ж причини провокують самогубство серед медиків? Перш за все - велике моральне навантаження: відповідальність за життя, здоров'я пацієнтів, перебування в жахливому середовищі вічного людського болю та страждань; не менш стомлююче очікування результатів лікування. «Кожному лікарю, за зауваженням покійного професора Шарко, доводилося працювати весь день в стомлюючій моральній атмосфері, наповненій концентрованими людськими стражданнями» [6, с. 16]. Часто бувають випадки, коли лікар, особливо молодий, дотримуючись науки не виліковує пацієнта, хворий помирає. Тим не менше, медик винить себе в його смерті, а не недосконалість науки. «Ця відповідальність підтримує в лікаря постійну напругу, котра нерідко є надзвичайно стомлюючою, особливо в молоді роки, коли лікар не вміє ще провести межі між своєю особистою відповідальністю і відповідальністю медичної науки, яка в деяких питаннях може бути також безсильна, як і окремі іiї представники» $[6$, с. 16]. Це почуття вини, моральна тяжкість виснажують душу лікаря, так би мовити тягне іiі на дно, i, якщо вчасно не надати йому допомогу, призводять до того, що часто медик шукає забуття в алкоголі, в наркотичних речовинах, що тільки більше підштовхує його до фатального вчинку. Нерідко трапляються випадки, коли лікар, виснажений почуттям вини, не бачачи іншого виходу і покінчує 3 життям. «Стомлення, котре природньо випливає з цього напруження, складає одну з самих звичайних причин занепаду духу та песимізму, що призводять до самогубства» [6, c. 16].

До негативних факторів, які сприяють збільшенню кількості самогубств серед медиків, також відноситься «ненормованість» робочого дня, низький соціальний захист. Відзначимо також неправильне агресивне ставлення мас-медіа, суспільства до окремих лікарів, з узагальненим направленням проти всієї групи, що є ще одним чинником суїциду. Цікавим $є$ той факт, що зазвичай спостерігаємо нарікання на медиків, та дуже рідко можна зустріти слова, котрі виправдовують їх дії, слова підтримки. «Хто хоча $б$ на хвилину стане психологом зрозуміє, що кому довірено охорону однієї 3 найвизначніших цінностей - людського життя, той надзвичайно чутливий і до несхвалення, і до засудження. Не можна робити докорів людині, доки вона несе важку ношу, в тому числі і медикам...» [6, с. 19]. Відповіддю всім цим наріканням і осудженням є така велика кількість самогубств серед медиків. «Ці цифри свідчать також і про чутливість лікарів до морального обов'язку: в суворій реальності цих даних - скажемо словами Морселлі відображаються факти людської совісті» [6, c. 20].

Останніми роками, як констатує статистика, стрімко зростає кількість самогубств серед підлітків та молоді - вікова категорія 15-30 р. Чому це відбувається? Як і в суїциді будь-якого іншого віку існує багато чинників. «Вже перші автори, які звертались до проблеми суїцидальності у підлітків вказували на зв'язок цих проявів не 3 патопсихологічними чинниками, а хибами виховання, браком моральності (В.М. Бех- 
тєрєв, І.О. Сікорський)» [10, с. 388]. Також даний вік відрізняється особливостями психофізіологічного розвитку, які сприяють суїцидальним діям. «Для юності характерна яскравість та сила почуття життя (Гефдінг), але при цьому не розвинута сила волі, яка досягає свого повного розвитку у більшості людей в 26-30-річному віці» [3, с. 36]. «Сприяють суїцидальності у підлітковому віці й особливості їхнього психофізіологічного розвитку: імпульсивність, емоційна незрілість і нестійкість» [10, с. 388].

Вже певний час в нашому суспільстві одне з видних місць займає проблема екзистенції (Хто Я? Для чого Я живу? Чому Я народився саме зараз, і саме в цьому місці?). Особливо чутливо переживається вона молодою душею, коли певні ідеальні погляди зіштовхуються з сірою буденністю, грубістю, байдужістю, з повною протилежністю. Ось тут виникає проблема буття. Аналізуючи даний момент, I. О. Сікорський зазначив наступне: «Важкі питання життя, буття і буденності в їх ідеалізації та ідеальній постановці, властиві юному вікові, призводять нерідко до важких сумнівів» [3, с. 37-38]. «Сумніви, які довго не вирішуються, або взагалі невирішені поступово покидають свідомість, «забуваються» i стають менш наполегливими, «губляться», опускаючись в океан безсвідомих вод (Джерстоу), але не пропадають безслідно» [3, с. 37-38]. «Небезпека сумнівів, особливо сумнівів невирішених і загублених, полягає в тім, що на грунті них виникає почуття вини перед собою. Це почуття в юному віці відіграє визначальну роль, як етіологічний (причинний) момент самогубства» [3, с. 38]. А ось що зазначають наші сучасники Пейакович Йу. Пурич, Душан Й. Дуніч «Як же найде себе підліток, коли він зіштовхується 3 тим, що ідеалізм знаходиться на лавці підсудних і відповідає за свої ілюзіï? Підліток (і це природньо) несе в собі потребу боротись за певний ідеальний світ. На цьому шляху він відкриває в собі кризу сенсу життя і тоді опиняється на порозі самогубства» [8, с. 157].

В зазначеній віковій категорії особливо небезпечним є період 29-30 років, згідно статистики більшості країн світу. І це недаремно так: в науковій психології одним 3 двох найбільш кризових являється 30 рік життя, а в традиційній східній психології — 29. На цьому проміжку часу відбувається переоцінка всіх попередніх життєвих цінностей, орієнтирів, народжується нова особистість. В людини знову виникає велика кількість сумнівів, які набагато глибші ніж у підлітковому віці. Ці сумніви, «котрі торкаються моральних питань та обов'язку, складають початкову точку майбутньої страшної катастрофи» [3, с. 38]. Саме в цей час ніби незначні проблеми можуть призвести до трагічного кінця.

Провівши дане дослідження суїциду, зупинимось на тому, як зменшити кількість цього явища. I.О. Сікорський притримувався погляду, що: «В питаннях самогубства найбільше значення мають релігійна і філософська директиви: про ціль життя, про обов'язок перед іншими, про обов'язок перед самим життям, про уявлене, але по суті, глибинно помилкове право зруйнувати власне життя і т.д.» [3, с. 8]. Тобто потрібно формувати екзистенційні, моральні цінності, та не просто їх створити, а весь час підкріплювати. Тому що: «Ідеалізм представляє... правильний запобіжний засіб проти самогубства» [12, с. 6]. Може одразу виникнути думка: «Таке виховання відбувається в усіх закладах освіти». Але сумна статистика свідчить про інше. I не тільки сухі цифри говорять про кількість самогубств, але й актуальність даного аспекту серед вчених. Візьмемо хоча б для прикладу білорусів: «Для юного населення вже зі шкільного віку (рівень соціально-оздоровчий), і краще всього вже з перших класів, потрібно ввести спеціальний предмет «Виховання і самовиховання сенсу життя» 3 акцентами на виховання сенсу, прищеплення основних моральних цінностей...; цінностей відношень» $[13$, с. 38$]$. Можливо вже настав час прислухатись до порад вчених, які лунають більше ста років?

Що стосується підліткового віку, то відзначимо цікаву пораду сербів: «Тільки 
творчі пригоди можуть звільнити підлітків від суїцидних думок» [8, с. 159].

Також дієвим методом $є$ перенаправлення русла свідомості людини на якусь альтруїстичну роботу, коли вона не думає про себе, і отримує задоволення від подяки, від своєї значущості.

Та все ж найкращим дієвим засобом проти самогубств виступає формування та підкріплення моральних, екзистенційних цінностей. Формування ідеальної сторони людського існування, котра відрізняе людину від тварини, являється вагомим чинником її розвитку. «Ідеалізований психізм - неочікувано-негадано для самої людини - переносить її на нові шляхи, в нову сферу дій — перероджує людину, як виражається людська мова» $[12$, с. 7].

Результати дослідження. Проаналізовано чинники, які провокують виникнення суїциду. Визначено шляхи запобігання самогубства.

Висновки та перспективи подальшого дослідження.

- Кількість самогубств невпинно зростає.

- Останні роки значно зросла кількість суїцидів серед вікової категорії 15-30 років.

- Однією з основних причин самогубства $є$ криза життєвих цінностей та орієнтирів.

- Для зниження кількості суїцидів потрібно проводити роботу по створенню і підкріпленню цінностей та орієнтирів, особливо акцентуацію слід зробити на моральних цінностях.

- Одним 3 напрямків роботи із зниження кількості самогубств повинна бути профілактика психічних перенапружень.

\section{Список використаних джерел:}

1. Сикорский И. А. Психологическая борьба с самоубийством в юные годы / И. А. Сикорский. - Киев : Типография Т-ва И. Н. Кушнерёв и К, 1913. - 44 с.

2. Сикорский И.А. Идеализация и материализация жизни : речь, произнесённая на Московском съезде психиатров в память С. С. Корсакова, 11 сентября 1911 г. // И. А. Сикорский. — Издание 2-е. - Киев : Тип. С. В. Кульженко, 1912. — 14 с.

3. Пурич Пейакович Йу. Самоубийство подростков / Пейакович Йу. Пурич, Душан Й. Дуньич // Пер с сербск. - М. : Медицина, 2000. - 168 с.

4. Сикорский И.А. Эпидемически вольные смерти и смертоубийства в Терновских хуторах (близ Тирасполя) / И. А. Сикорский // Вопросы нервно-психической медицины. — 1897. - T. 2. - C. 453-511.

5. Сикорский И. A. Dumas. Опытное исследование состояние радости и печали / И. А. Сикорский // Вопросы нервно-психической медицины. - 1897. - Т. 2. - С. 122-123.

6. Сикорский И.А. Самоубийство среди русских врачей / И. А. Сикорский // Вопросы нервно-психической медицины. - 1896. - Т. 1. - С. 9-20.

7. Москаленко В. Ф. Проблема самогубств в Україні / В. Ф. Москаленко // Науково-практичний журнал Охорона здоров'я України. — № 2 (30). — 2008. — С. 29-33.

8. Чуприков А. П. Суицидология как часть охраны психического здоров'я / А. П. Чуприков // Таврический журнал психиатрии. - Т. 3. — №3 (10). — 1999. - С. 23-27.

9. Кузнецов М. Т. Суицидальное поведение: причинность и задачи профилактики / М. Т. Кузнецов // Здравоохранение. - №7. - Минск, 1999. - С. 37-38.

10. Турбан В. В. Підлітковий суїцид як етико-психологічний феномен / В. В. Турбан // Актуальні проблеми психології : збірник наукових праць Інституту психології ім. Г. С. Костюка АПН України / за ред. Максименка С. Д. - К. : Логос, 2007. - Т. 7. — Вип. 10. — С. 296301.

11. Турбан В.В. Самогубство як соціокультурний феномен / В. В. Турбан // Соціальна психологія. Науковий журнал. — 2012. — №3 (53). — С. 100-108.

12. Київська правда [Електронний ресурс]. - Режим доступу : http://kpravda.com/v-armiissha-zaregistrirovano-rekordnoe-kolichestvo-samoubijstv/

13. Біомедичний журнал Медичні новини [Електронний ресурс]. - Режим доступу: http://www.medline.ru/news/news.phtml?n=169 
Аннотация. Данное исследование посвящено проблематике самоубийства. В основу статьи было взято творческое наследие И.О. Сикорского, которое относится к этой теме. В работе приведен перечень профессий, где происходит самое большое количество суииидов, и сделан анализ причин их возникновения. Выделенные возрастные категории, которые боле подвержены самоубийству, и названы те факторы, что толкают людей к такому трагическому шагу. Акиентировано внимание на том, что одной из самых распространенных причин возникновения суицида есть кризис моральных и экзистеницильных иенностей. Для преодоления этой проблемы делается ударение на проведении разнообразной работы, нацеленной на создание и подкрепление иенностей и ориентиров, особенно моральных.

Ключевые слова: Мораль, нравственность, суицид, моральные и экзистенциональные цеенности, формирование идеализма, воспитание.

Abstract. We carried out the analysis of ancient literary sources. Evidences about the suicides are in many books. The conclusion of this analysis is that people were killing himself throughout history of mankind. All the time reasons of origin of suicide, attitude toward him and his interpretation are changing. We all know what is suicide. But will be better if we will give the suicide definitions that there was no confusion. Suicide is the act of purposely ending one's own life. Freedom and awareness are necessary components of this act. When someone forces the person to commit the suicide, when someone drive his mental condition to the action, which is directing him on self-destruction, it is murder, but isn't suicide. Among what group of people are most often committed suicide? If we look at statistics on age, we will see that for the last years the most large number of suicides is registered among people from 15 to 30 years. Why is this happening this way? In this period of people's life two large crises are places - puberty crisis and crisis 30 years. At this age there is "ssearch itself», also the man reconsiders his vital values. All this makes a great strain on the human psyche. Sometimes the result of all of it may be suicide. We analyzed the number of suicides among people of different professions. On the first place there are doctors. On the second place - teachers. The strong moral pressure exhausts people of these professions. The strong moral pressure causes dejection and cheapens values of life. The loss of moral ideals often leads to suicide. If we create and strengthen values of life, it will reduce number of suicides. Moral values have especially strong influence on people in this process.

Keywords: moral, formation of idealism, a suicide, moral and existential values, morality, self-destruction. 